\title{
HEAVY METALS IN POULTRY AND FISH FEED INGREDIENTS IN BANGLADESH: A POTENTIAL THREAT TO OUR NEXT GENERATION
}

\author{
Asia Akter \\ Lecturer \\ Department of Soil Science, \\ Dhamrai Govt. College, Dhaka \\ Ministry of Education \\ People's Republic of Bangladesh
}

\author{
Prof Dr. Md. Nadiruzzaman Mondol, \\ Prof Dr. Afrose Sultana Chamon, \\ Prof Dr. Syed Mohammad Abul Faiz \\ Faculty member, Professor \\ Department of Soil, Water and Environment, \\ University of Dhaka
}

\begin{abstract}
Hazaribagh the area of leather processing industries; is the main place of Bangladesh from where the poultry and fish feed have produced and supplied all over the country. Solid tannery waste and sliced- cut pieces of skin and hide are proteineceous. These wastes are converted to protein - concentrate to be used in poultry feed, fish feed and bio fertilizer without any appropriate treatment. Although total Chromium content in tannery waste based poultry and fish feed has been determined previously but no studies appear to have been on others heavy metals i.e. $\mathrm{Zn}, \mathrm{Pb}, \mathrm{Cd}, \mathrm{Ni}, \mathrm{Mn}$ and $\mathrm{Fe}$. AAS is used to determine the heavy metals concentration in ppm. A total three types of sample were collected from different location of sampling site. The sample represents the various stages of protein - concentrate production from solid waste to final products i.e. poultry and fish feed ingredients. All heavy metals were not only detected in all sample type but also significantly higher than the MAC value for poultry and fish feed ingredients and cross the permissible limit for human.
\end{abstract}

Keywords: Heavy Metal, Poultry feed, Feed Ingredients

\section{INTRODUCTION}

The Hazaribagh tannery complex is located inside the greater Dhaka flood protection embankment. The embankment was built in the year 1989. When tanneries were initially allowed to operate in the Hazaribagh area, at the western part of the capital, close to Turag River, no planning had taken place
(Chowdhury et al., 1996). Tanners wash, dry and process raw hide and skin in factories and also in the open areas of Hazaribagh, which is a residential area adjacent to Lalbagh, Rayerbazar, Dhanmondi and Mohammadpur (Lake et al., 1984). The nearly 50-acre Hazaribagh area has now become a chemicallycontaminated hub. Emmerich et al., 1982, He et al., 1992, Lake et al., 1984 claim that children who work and live in nearby slums suffer chronic health ailments. Not a single factory in the country's largest leather zone has an Effluent Treatment Plant (ETP) to treat the highly-toxic water before release. He et al., 1992 found that The river Buriganga - have lost the ability to host aquatic species long ago.

At present there are 207 tanneries in Bangladesh with about annual Production of 485 million square $\mathrm{ft}$ hides and skin in association of 78,000 ton solid waste per year (Hashem and Tomal, 2015). Among these solid wastes major portions are shaving and buffing dust, trimmings, fleshing and fats. In Bangladesh, yearly $20.1 \times 103$ MT fleshing was generated only from cow hide and goat skin where $10.3 \times 103$ MT for cow hide and $9.8 \times 103$ MT for goat skin (Hashem and Tomal, 2015). 74000 ton/year chemical require for tanning process; each ton of raw hides requires $400 \mathrm{~kg}$ of different chemicals including sodium chloride, lime, sodium sulphide, sulfuric acid, basic chromium sulfate, dyes and others. Thus the impact of the waste produced from the tannery industry is significant.

Tannery waste is one of the most obnoxious, foulsmelling and toxic industrial wastes. The traditional disposal method for solid tannery waste is land-filling. But now a day solid tannery waste are using as the principal component of poultry and fish feed, but it has been recently banned by the 


\section{International Journal of Engineering Applied Sciences and Technology, 2020 Vol. 5, Issue 8, ISSN No. 2455-2143, Pages 64-70 \\ Published Online December 2020 in IJEAST (http://www.ijeast.com)}

Supreme Court of Bangladesh because of its possible adverse health effects for the consumers. Some profit mongering dishonest traders are engaged in producing the feed ignoring the ban and supplying those in different areas of the country.

Poultry farming and fish cultivation are the promising sector of Bangladesh and important sources of protein. Poultry farming and fish cultivation are generally done for fish, meat and egg. There is an estimated 150,000 poultry farms in Bangladesh (The Daily Star, 2017); Provita feed, Kazi farms, Nourish are leading ones. The farms annually produce 570 million tones of meat and 7.34 billion eggs (The Daily Star, 2017).

In Bangladesh, poultry and fish feed producers using skin-cut waste from tannery industries as a protein source because of its costless availability. Use of this chrome skin-cut waste in poultry feed production as protein source without appropriate treatment would create a potential health risk of heavy metals in food chain (Maruf et al., 2007).

In our present study we found that Hazaribagh is the main place from where the contaminated poultry and fish feed have supplied all over the country. In general, to use the protein concentrate for poultry feed, it is boiled with a mixture of $\mathrm{H}_{2} \mathrm{SO}_{4}$ and water in a big container for 3 to 4 hours. After cooling, liquid is removed from the container and the concentrate of treated shaving dust is dried in the sunlight for few days and grinded to make powder. Powder is then mixed with other feed ingredients likes soya oil cake, corn grain and dried fish to make final feed. The practice of using tannery waste for fish and poultry feed began around 10 years ago as the price of imported protein for fish and poultry feed has gone up over the years.

Although metals like iron, copper, zinc and manganese are essential and they play an important role in biological system but the metals like cadmium, lead, and mercury are toxic even in trace amount (Munoz et al., 2001). All mineral elements, whether it is theorized as essential or Potentially toxic, may have an adverse effect if included in the diet at excessively high concentration (Okoye et al., 2011). The toxicity of tannery waste is primarily due to the presence of chromium. Amongst the available tanning methods, chrome-tanning is the most popular where chromium sulfate is added as a tanning agent. The use of tannery waste in producing poultry and fish feed poses serious risks to human health as people are eating fish and meat fattened by such toxic feed. The Bangladesh Pure Food Ordinance 2005 prohibits the use of any poisonous chemicals or ingredients in any food items, which may cause harm to humans. Under such situation this research work was done to determine the amount of heavy metals present in various stages of protein concentrate production from solid waste to raw feed ingredients.

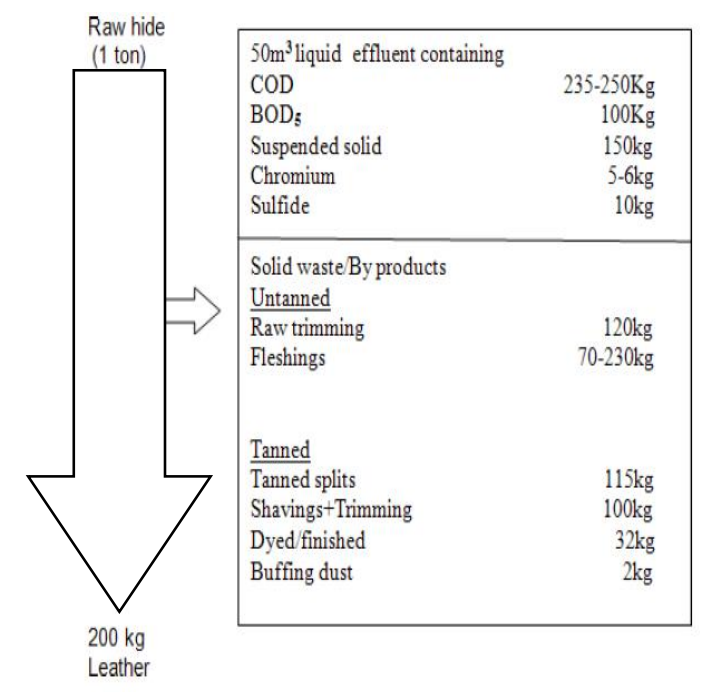

Figure 1: Production of tannery waste in leather processing

\section{SAMPLING}

For the research purpose, the protein- concentrate production process practiced at Hazaribagh were first surveyed and observed. In addition locals of sampling are were interviewed. These interviews help us to know the entire process how tannery solid waste and skin cuts waste are mixed with other poultry and fish feed. 3 types of sample were collected in clean plastic Ziploc bags. The sample represents various stages of protein concentrate production from solid waste to final products. Samples were collected from different spots of Hazaribagh- kamrangir char. These areas were feed mills of Hazaribagh, Nimtoli poultry market, huzur para kamrangir char Dhaka. The sampling points were geo references with GPS. GPS locations of sampling points and overall map of sampling area are given in the following table 1 and figure 2 : 


\begin{tabular}{|ccc}
\hline $\begin{array}{c}\text { No of } \\
\text { sampling } \\
\text { site }\end{array}$ & Latitude & Longitude \\
$\mathbf{1}$ & $23^{0} 44.67^{\prime} \mathrm{N}$ & $90^{0} 21.54^{\prime} \mathrm{E}$ \\
\hline $\mathbf{2}$ & $23^{0} 44.01^{\prime} \mathrm{N}$ & $90^{0} 21.807^{\prime} \mathrm{E}$ \\
$\mathbf{3}$ & $23^{0} 44.50^{\prime} \mathrm{N}$ & $90^{0} 21.10^{\prime} \mathrm{E}$ \\
\hline
\end{tabular}

Table 1: GPS location of sampling points

\section{SAMPLE CLASSIFICATION WITH IDENTITY}

Sample Type I: Raw solid waste Greenish blue in color, it includes flesh, skin-cuts of different parts. Dumped in open space and then stored inside the room. These samples were collected in front of feed mill of Hazaribagh.

Sample Type II: Sun dried solid waste Faded greenish- blue in color. Solid wastes boiled and dried in sun, collected from local producer hugur para, Kamrangir char.

Sample Type III: Raw feed ingredients Faded grey in color, ready to use as feed ingredients for fish and poultry, collected from Nimtoli poultry market.

\section{SAMPLE DIGESTION}

The wet and moist samples were sun dried to remove sensible moisture. Then the samples were oven dried. Samples were digest with $\mathrm{HNO} 3-\mathrm{HClO} 4$

For all heavy metal analysis the prepared sample were performed through atomic- absorption spectrophotometer (AAS). The samples were prepared by using $\mathrm{HNO} 3$ - $\mathrm{HClO} 4$ digestion (kebbekus and Mitra,b 1998). Since the samples were of organic origin with a very high organic content, HNO3 - HClO4 was prepared over more common HNO3 extraction for the determination of heavy metals. This strongly oxidizing digestion decomposes organics quickly and efficiently.

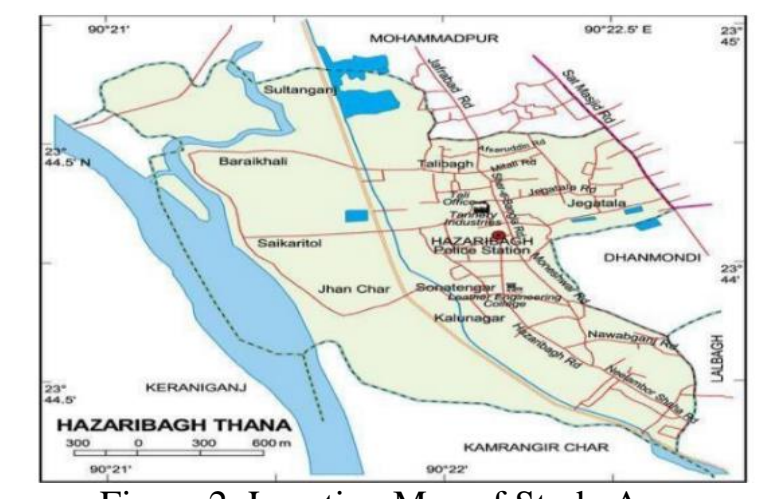

Figure 2: Location Map of Study Area

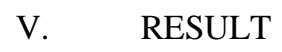

By AAS we analyzed total seven $(\mathrm{Cr}, \mathrm{Zn}, \mathrm{Pb}, \mathrm{Ni}, \mathrm{Cd}$, $\mathrm{Mn}$ ) heavy metals concentration of collected samples. The results for each sample type are given table 2 :

Cr

Chromium facilities the action of insulin as well as helps to the metabolism and storage of carbohydrates, fat and protein (Anderson, 1997). But excessive level of $\mathrm{Cr}$ in fish and poultry feed damages the kidneys, the liver and blood cells through oxidation reaction (Dayan and paine, 2001). In case of $\mathrm{Cr}$ maximum conc were found in sample type 1 (7254.3 ppm). High concentration may be found due to use of huge amount of chromium sulphate $(\mathrm{CrSO} 4)$, regarded as one of the most effective tanning agent. During liming, pickling and curing stage huge amount of chromium phosphate are also used. Those salts are used to remove hairs, nails and other keratinous materials and to remove the natural grease and fats. Comparative lower value of $\mathrm{Cr}$ was observed at sample type III i.e raw feed ingredients. It may be due to washing $\mathrm{g}$, boiling and drying treatment of sample. Cr concentration in sample type III cross the MAC value $(0.10 \mathrm{ppm})$ for fish and prawn feed ingredients (Fish feed and Animal feed act-2010). The results obtained from our study were alarming. The assessment showed that sample type $\square \square \square$ contains $\mathrm{Cr} 4728$ ppm. Several times higher than maximum Chromium consumption level $(5 \mathrm{mg} / \mathrm{Kg}$ The major concern about $\mathrm{Cr}$ is that it has carcinogenic behavior in human (Baruthio, 1992). Ikem and Egilla 2008 have reported that the average elemental concentration of $\mathrm{Cr}$ is $1.42 \mathrm{mg} / \mathrm{Kg}$ in diet of fish feed which is the acceptable limit and much lower than our findings. 
International Journal of Engineering Applied Sciences and Technology, 2020

Vol. 5, Issue 8, ISSN No. 2455-2143, Pages 64-70

Published Online December 2020 in IJEAST (http://www.ijeast.com)

$\begin{array}{cccccccc}\text { Type } & \mathbf{C r} & \mathbf{Z n} & \mathbf{P b} & \mathbf{C d} & \mathbf{M n} & \mathbf{F e} & \mathbf{N i} \\ \text { Sample type I } & 7254.3 & 1982.7 & 92.0 & 2.1 & 145.2 & 8741.1 & 379.4 \\ \text { Sample type II } & 6187.8 & 1813.6 & 86.1 & 1.4 & 143.5 & 7782.8 & 264.2 \\ \text { Sample type III } & 4728.0 & 850.08 & 73.5 & 1.08 & 101.2 & 7791.1 & 210.3\end{array}$

Table 2: Heavy metals concentration in ppm in different samples type.

\section{Zn:}

It is well known that $\mathrm{Zn}$ is an essential element for animal including human. $\mathrm{Zn}$ deficiency results in growth inhibition in animals (Macdonald, 2000). That's why Zn is used in poultry and fish feed ingredients. But boilers performance was not affected by $\mathrm{Zn}$. According Institution of medical, food and nutrition board of USA, 2001 recommended Dietary Allowance- RDA for Zincs are $40 \mathrm{mg}$ of $\mathrm{Zn}$ a day to be the upper limit dose for adults.

\section{Pb:}

In 2012 the Center for diseases control and prevention (USA) has set the standard elevated blood $\mathrm{Pb}$ level for adults to be $10 \mu \mathrm{g} / \mathrm{dL}$ of the whole blood (CDC, 2012). Mean concentration of $\mathrm{Pb}$ obtained was $83.86 \mathrm{ppm}$ which exceeded the limit $5 \mathrm{mg} / \mathrm{kg}$ of $\mathrm{Pb}$ in feed stipulated by EU, 2003.

\section{Cd:}

The detected maximum and minimum concentration of Cadmium was found 2.1 and $1.08 \mathrm{ppm}$. $\mathrm{Cd}$ is non essential nutrients that are of direct concern to human and livestock health and may accumulate in the body particularly in the kidney, liver and to a lesser extend in the muscle ( $\mathrm{Li}$ et. al 2005). "International Agency for Research on Cancer" has classified Cd and its compound on Group I human carcinogen (IARC,1993). The effects of $\mathrm{Cd}$ poisoning in humans are very serious among there are high blood pressure, kidney and damage destruction testicular tissue and destruction of red blood cells (Manahan, 1997).

\section{Ni:}

The most serious harmful health effect of nickel is chronic bronchitis, reduced lung function, and cancer of the lung and nasal sinus. The International Agency for Research on Cancer (IARC) has determined that some nickel compounds are carcinogenic to humans and that metallic nickel may possibly be carcinogenic to humans. Food contains nickel is the major source of nickel exposure for the general population. According to Agency for Toxic Substances and Disease RegistryATSDR about 170 micrograms of nickel in our every day meal is highest permissible limit for Ni. But in our study we found about $284.63 \mathrm{ppm} \mathrm{Ni}$ averagely in all samples which cross the permissible limit of food.

\section{Mn:}

In case of Mn maximum concentration were found in sample type I (145.2ppm). High concentration may be found due to use of huge amount of Manganese Oxide $\left(\mathrm{MnO}_{2}\right)$ regarded as one of the most effective oxidizing agent. $\mathrm{MnO}_{2}$ are generally used decolorized the leather. The general population is exposed to manganese through consumption of food and water. The primary source of manganese intake is through diet. The Food and Nutrition Board (FNB) of the Institute of Medicine (IOM) has set adequate intake (AI) levels for manganese for human that is $2.3 \mathrm{mg} /$ day. There is no evidence that manganese causes cancer in humans. Although no firm conclusions can be drawn from the mixed results in animal studies, there are little data to suggest that inorganic manganese is carcinogenic.

\section{Fe:}

$\mathrm{Fe}$ is an essential element for human. Iron deficiency may go to anemia. But Fe also has an adverse effect on human body when excess amount of Fe are intake. Toxic effects begin to occur at doses above $20 \mathrm{mg} / \mathrm{kg}$ of elemental iron. Average Iron content in different sample type is 8105 ppm which is alarming. More over 7791.1 ppm of Fe was detected in Sample type III. There is a possibility of Fe to enter into food chain by these contaminated feed ingredients. 
International Journal of Engineering Applied Sciences and Technology, 2020

Vol. 5, Issue 8, ISSN No. 2455-2143, Pages 64-70

Published Online December 2020 in IJEAST (http://www.ijeast.com)

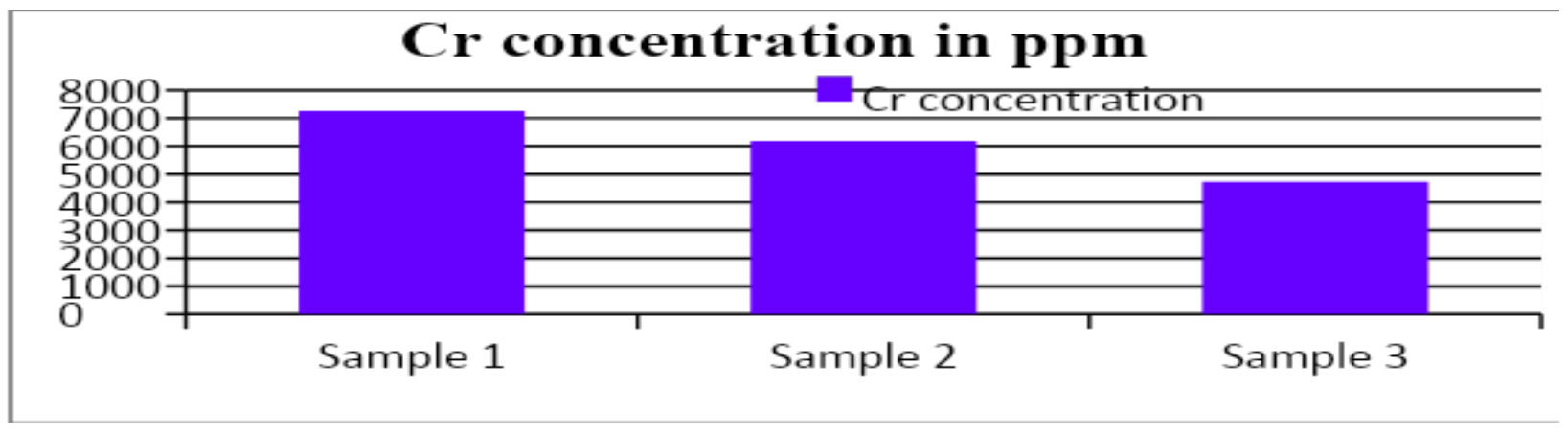

Figure 3: $\mathrm{Cr}$ in ppm in different sample type

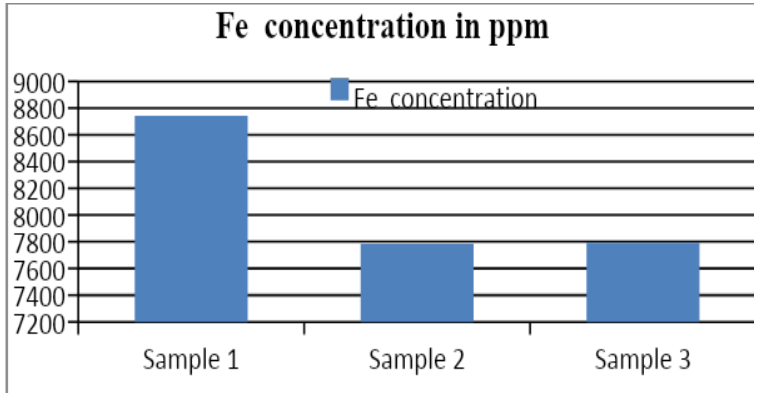

Figure 4: Fe in ppm in different sample type

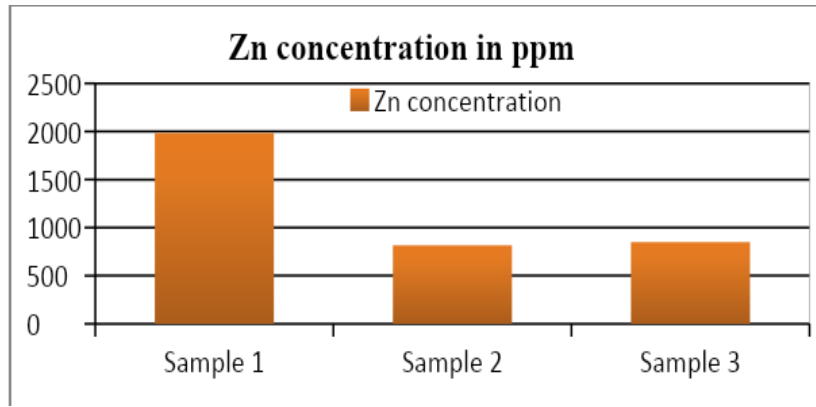

Figure 5: $\mathrm{Zn}$ in $\mathrm{ppm}$ in different sample type

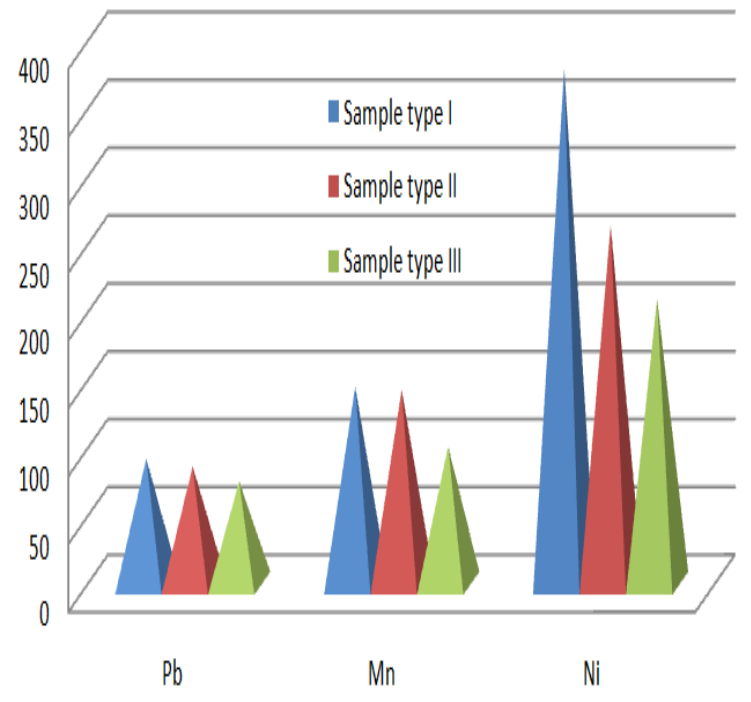

Figure 6: $\mathrm{Pb}, \mathrm{Mn}$ and $\mathrm{Ni}$ in ppm in different sample type

\section{CONCLUSION}

According to the present study it is clear that contaminated $\mathrm{Cr}, \mathrm{Zn}, \mathrm{Pb}, \mathrm{Cd}, \mathrm{Ni}, \mathrm{Mn}$ in the feed ingredients in Hazaribagh area are very serious. The average $\mathrm{Cr}$ content in all sample type was several times higher than allowed $\mathrm{Cr}$ concentration for tannery waste in capital. Poultry and fish feed produced by animal waste without proper sterilization may contain bacteria, aflatoxins and 


\section{International Journal of Engineering Applied Sciences and Technology, 2020 \\ Vol. 5, Issue 8, ISSN No. 2455-2143, Pages 64-70 \\ Published Online December 2020 in IJEAST (http://www.ijeast.com)}

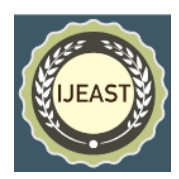

other elements. Although the high Court of Bangladesh have already banned the use of tannery waste to make poultry and fish feed but still now some dishonest poultry and fish feed producer are producing poultry and fish feed using such toxic human foods. Consumption of tannery waste through eating fish and poultry might lead to liver and kidney diseases and even cancer. In a country like Bangladesh it will be very difficult to enforce this ban because it is a profitable business and large numbers of people are involved here. It is therefore suggested that regular survey of heavy metals especially $\mathrm{Cr}, \mathrm{Cd}$, Ni should be done to evaluate health risk and to find possible measure to avoid the health injury. Before using the tannery waste as feed ingredients Treating the waste and bring the heavy metals to a safe level should be another better option.

\section{ACKNOWLEDGEMENT}

This study deal with heavy metals contamination in poultry and fish feed producing in Hazaribagh area, Dhaka. Experiments were conducted in different Laboratory of department of Soil Water and Environment, University of Dhaka and Bangladesh Council of Scientific and Industrial Research (BCSIR). We are grateful to the head of department of SWED and chairman of BCSIR for their continues inspiration. We would like to express our cordial thanks to tannery workers, poultry feed producer and traders in Hazaribagh area for their co operation, suggestion and assistance for sample collection.

\section{REFERENCES}

[1] Anderson R. A. Chromium is an essential nutrient for humans. Regulatory toxicology and pharmacology. 1997; 26(1): 35-41.

[2] Bangladesh Pure Food Ordinance 2005; https://mofl.gov.bd/site/view/law/Fish-and-

Livestock-related-all-laws.

[3] Bangladesh Fish feed and Animal feed act 2010.

[4] Baruthio, F. (1992) Toxic effects of chromium and its compounds; Biol Trace Elem Res. 32: 145-53.

[5] CDC Response to Advisory Committee on Childhood Lead Poisoning Prevention Recommendations in "Low Level Lead Exposure Harms Children: A Renewed Call of Primary Prevention".

[6] Chowdhury. F. J. Imamul Huq. S. M. and Aminul Islam. M. 1996. Accumulation of polluents by some aquatic macrophytes found in the Buriganga River. Proceeding of the 25th Bangladesh science conference. DOE 1992. Training Manual on Environmental management.
[7] Dayan A D, Paine A J. Mechanisms of Chromium toxicity, carcinogenicity and allergenicity review of literature from 19850to 2000. Human and Experimental toxicology. 2001; 20(9):439-451.

[8] Emmerich. W E; L J Lund A L. Page. And AC Chang. 1982. Solid phase forms of heavy metals in sludge sludge-treated soils. J. Environ. Ouality 11: pp.178-181.

[9] European commission. Opinion of the scientific committee on animal nutrition on undesirable substances in feed. European commission, Health and consumer protection Directorate, Brussels, Belgium, 2003.

[10] Hashem M. A., Nur-A- Tomal M. S., "Generation of flashings at beam house in tannery and its environmental impact assessment: Bangladesh perspective", Bangladesh Journal of scientific and Industrial Research 50(3), 227-232, 2015.

[11] He XT; Traina S. J. and Logan T.J. 1992. Chemical properties of municipal solid waste compost. J. Environ. Quality 21: pp.318-329.

[12] IARC. (1993) Cadmium and Cadmium Compounds, vol. 58, pp. 119-237. IARC Monographs on the Evaluation of 2(3), 2011, 6368.Carcinogenic Risks to Humans. Lyon: International Agency for Research on Cancer.

[13] Institute of Medicine, Food and Nutrition Board. Dietary Reference Intakes for Vitamin A, Vitamin K, Arsenic, Boron, Chromium, Copper, Iodine, Iron, Manganese, Molybdenum, Nickel, Silicon, Vanadium, and Zinc. Washington, DC: National Academy Press, 2001s

[14] Ikem A, Egilla J. Trace element content of fish feed and bluegill sunfish from aquaculture and wild sourcesin Missouri. Food chemistry. 2008: 110(2):301-309.

[15] Kebbekus, B. B., Mitra. S. (1998) Environmental Chemical Analysis. Pub. Blackie Academic and professional. London.

[16] Lake. D.L; PWW. Kirk and J.N. Lester. 1984. Fractionation. Characterization and speciation of heavy metals in sewage and sludge amended soil. A review. J. Environ. Quality. 13: pp. 175-183.

[17] Li, Y., McCory, D.F. Powell, J.M. Saam, H. and Jackson-Smith D.2005. J. Dairy Sci. 88: 2911-2922

[18] Maruf H. A. M. M, M. Tasbee, H. A. M. Rezwan - Ul, K. M. A. Islam, I. M. Shahidul and E. S. Fazle, Heavy Metal Concentration in Tannery Solid Wastes Used as Poultry Feed and the Ecotoxicological Consequences, Bangladesh Journal of Scientific and Industrial Research,42(4), 2007, $397-$ 416.

[19] MacDonald R. S. The role of zinc in growth and cell proliferation. Journal of Nutrition 2000; 130:1500s-1508s. 
[20] Manahan, S.E. (1997) Environmental Science and Technology.CRC Press/Lewis Publishers, Boca Raton

[21] Munoz R. -Olives, C. Camara. Speciation related to human health, In L. Ebdon, L. Pitts, R. Cornelis, H. Crews, O. F. Donard, P. Quevauviller. Trace element speciation for environment food and health. The Royal Society of Chemistry, 2001, 331353.

[22] The Daily Star."Poultry operators eye global market". The Daily Star. 2017-03-05

[23] Okoye C. O. B, C. N. Ibeto and J. N. Ihedioha, Assessment of heavy metals in chicken feeds sold in south eastern, Nigeria. Advances in Applied Science Research 